\title{
Molecular diagnosis of avian viruses in grassland passerines and captive yellow cardinals Gubernatrix cristata in Brazil ${ }^{1}$
}

\author{
Bianca R. Silva²*(D), Thais H. Gamon², Angélica C.A. Campos³ (iD, \\ Luciano M. Thomazelli ${ }^{3}$, Patricia P. Serafini ${ }^{4}$, Eduardo Chiarani ${ }^{5}$, \\ Thaiane W. Silva ${ }^{5}$ and Rosangela Locatelli-Dittrich ${ }^{2}$
}

\begin{abstract}
Silva B.R., Gamon T.H., Campos A.C.A., Thomazelli L.M., Serafini P.P., Chiarani E., Silva T.W. \& Locatelli-Dittrich R. 2021. Molecular diagnosis of avian viruses in grassland passerines and captive yellow cardinals Gubernatrix cristata in Brazil. Pesquisa Veterinária Brasileira 41:e06840, 2021. Graduate Program in Veterinary Sciences, Setor de Ciências Agrárias, Universidade Federal do Paraná, Rua dos Funcionários 1540, Curitiba, PR 80035-050, Brazil. E-mail: biaressetti@gmail.com

Avian influenza viruses (AIVs), Newcastle disease virus (NDV), West Nile virus (WNV), adenovirus (AV) and herpesvirus (HV) play an important role in the health of human and animal populations. However, knowledge of the prevalence of these viruses in wild birds is restricted to some groups (e.g. shorebirds) or regions worldwide. Information on grassland birds of South America, which is essential for their conservation, is scarce. The objectives of the present study were to evaluate occurrences of AIV, NDV, WNV, AV and HV for the first time in a bird community of a unique protected area in southern Brazil, which is home for the critically endangered yellow cardinal (Gubernatrix cristata), and captive yellow cardinals from fauna maintainers of the Brazilian Captive Program of the Yellow Cardinal. Passerine species of wild life were caught, identified and samples (swabs) were collected from the oropharynx and cloaca of 64 passerines of 26 species (including 3 yellow cardinals) and 30 yellow cardinals of captive, for molecular diagnosis. The samples were subjected to RNA and DNA extraction and the real-time polymerase chain reaction (RT-PCR) for AIV, NDV and WNV and nested PCR for AV and HV. One yellow cardinal of captive presented a positive result for $\mathrm{AV}$, this result is important for planning, managing natural attributes and making decisions in relation to integrated conservation of threatened species. This is the first report of AV in yellow cardinal and epidemiological investigation of viruses in wild passerines of the Pampa biome, in Rio Grande do Sul, Brazil.
\end{abstract}

INDEX TERMS: Molecular diagnosis, avian virus, passerines, yellow cardinals, Gubernatrix cristata, Brazil, conservation, pampa, sanitary profile, thornbush, threatened species, wildlife animals.

RESUMO.- [Diagnóstico molecular de vírus aviários em passeriformes campestres e cardeais-amarelos Gubernatrix cristata cativos no Brasil.] Os vírus da gripe aviária (VGA), vírus da doença de Newcastle (VDN), vírus do Nilo Ocidental (VNO), adenovírus (AV) e herpesvírus (HV) desempenham um

\footnotetext{
${ }^{1}$ Received on February 16, 2021.

Accepted for publication on March 29, 2021

${ }^{2}$ Graduate Program in Veterinary Sciences, Setor de Ciências Agrárias, Universidade Federal do Paraná (UFPR), Rua dos Funcionários 1540, Curitiba, PR 80035-050, Brazil. E-mail: roslocdi@ufpr.br; *Corresponding author: biaressetti@gmail.com

${ }^{3}$ Laboratório de Virologia Clinica e Molecular, Instituto de Ciências Biomédicas II, Universidade de São Paulo (USP), Av. Professor Lineu Prestes 1374, São Paulo, SP 05508-900, Brazil. E-mails: thagamon@hotmail.com, camposac@usp.br, lucmt@usp.br
}

papel importante na saúde das populações humana e animal. No entanto, o conhecimento da prevalência desses vírus em aves selvagens é restrito a alguns grupos (por exemplo, aves limícolas) ou regiões em todo o mundo. As informações sobre as aves campestres da América do Sul, essenciais para a sua

\footnotetext{
${ }^{4}$ Centro Nacional de Pesquisa e Conservação de Aves Silvestres, Instituto Chico Mendes de Conservação da Biodiversidade (ICMBio), Rodovia Jornalista Maurício Sirotski Sobrinho Km 2, Florianópolis, SC 88053-700, Brazil. E-mail: patricia.serafini@icmbio.gov.br

${ }^{5}$ Laboratório de Ornitologia, Pontifícia Universidade Católica do Rio Grande do Sul (PUCRS), Campus Porto Alegre, Av. Ipiranga 6681, Porto Alegre, RS 90619-900,Brazil.E-mails: educhiarani@gmail.com, thaianews@gmail.com
} 
conservação, são escassas. Os objetivos do presente estudo foram avaliar a ocorrência de VGA, VDN, VNO, AV e HV pela primeira vez em uma comunidade de aves de uma área única protegida no Sul do Brasil, que abriga o cardeal-amarelo (Gubernatrix cristata) criticamente ameaçado de extinção e em cardeais-amarelos de cativeiro dos mantenedores de fauna do Programa Brasileiro de Cativeiro do Cardeal-amarelo. Espécies de passeriformes silvestres foram capturadas, identificadas e amostras (swabs) foram coletadas da orofaringe e cloaca de 64 passeriformes de 26 espécies (incluindo 3 cardeais-amarelos) e 30 cardeais-amarelos de cativeiro, para diagnóstico molecular. As amostras foram submetidas à extração de RNA e DNA e à reação em cadeia da polimerase em tempo real (RT-PCR) para VGA, VDN e VNO e nested PCR para AV e HV. Um cardeal-amarelo de cativeiro apresentou resultado positivo para $\mathrm{AV}$, este resultado é importante para o planejamento, manejo dos atributos naturais e tomada de decisões em relação à conservação integrada de espécies ameaçadas. Este é o primeiro relato de AV em cardeal-amarelo e de investigação epidemiológica de vírus em passeriformes silvestres do bioma Pampa, no Rio Grande do Sul, Brasil.

TERMOS DE INDEXAÇÃO: Diagnóstico molecular, vírus aviário, passeriformes, cardeal-amarelo, Gubernatrix cristata, Brasil, conservação, pampa, perfil sanitário, espinilho, espécies ameaçadas, animais selvagens.

\section{INTRODUCTION}

Development of a health assessment database for threatened passerine species is essential in order to determine the health status of populations. Such database can act as reference for monitoring as well as for future evaluation of these birds. It can potentially also underpin management decisions (release, reintroduction and population reinvigoration), thus contributing towards conservation initiatives among threatened taxa (Kolesnikovas et al. 2012). The yellow cardinal, Gubernatrix cristata, is among the threatened passerines inhabiting the "Parque Estadual do Espinilho", they are also found in the savannas of Argentina and Uruguay, however its natural history is relatively unknown (Jaramillo 2020). In a study that monitored the population of the yellow cardinal, in all known areas of its presence in the Espinilho savanna, only 53 individuals were encountered (Beier et al. 2017). According to "Instituto Chico Mendes de Conservação da Biodiversidade" (ICMBio), the tendency is the extinction of the species in Brazil if measures are not taken to curb capture and try to recover viable populations in the wild (Martins-Ferreira et al. 2013).

In the present study, five viruses, three important viruses with zoonotic potential and two avian infectious viruses were investigated among the grassland passerines in southern Brazil. The zoonotic viruses were: avian influenza viruses (AIVs), Newcastle disease virus (NDV), West Nile virus (WNV). The infectious agents investigated were: adenovirus (AV) and herpesvirus (HV).

Highly pathogenic subtypes of AIVs, family Orthomyxoviridae, have been responsible for endemic infections and outbreaks in many countries, causing the deaths of thousands of domestic and wild birds, along with significant economic losses (Kalthoff et al. 2010). The maintenance of AIV is dependent upon complex multiavian systems according to recent studies (Caron et al. 2017). With the exception of
Antarctica, passerines have habitats worldwide and should be considered within the ecology of AIVs because many of them freely intermingle with wild and domestic populations of waterfowl and poultry (Urig et al. 2017). The illegal trade of wild birds has also been identified as being an important role for spreading AIVs (Tian \& Xu 2015). Different subtypes of AIV were recently identified in migratory birds at an important stopover area in southern Brazil. There are scarce studies and surveillance on occurrences of AIVs in South America and Brazil (Araujo et al. 2018).

One of the most important viruses of avian species globally is the NDV, that belongs to the family Paramyxoviridae. Based on genetic characteristics, NDV is divided into two classes; class I and class II. The strains of class I are predominantly isolated from wild birds, in most cases have low virulence, and rarely are identified in poultry species. Class II NDV is more phenotypically diverse and exhibit a wider range of virulence (Dimitrov et al. 2016). Class II are the most important viruses for the avian species globally, with outbreaks that potentially can cause substantial economic losses to the poultry industry (Lugarini et al. 2018). There is need to improve the current pathotyping systems of identification of class II NDV so it can be rapidly and precisely identified and controlled before causing severe devastation and loss in poultry (Bello et al. 2018). Previously, serological studies were performed on backyard poultry flocks located near one of the main routes for migratory birds in Brazil, in Rio Grande do Sul, detected a high number of farms with seropositive birds. This result indicated that NDV is circulating in this region and that there is a risk that it might spread to local wildlife and commercial flocks (Marks et al. 2014).

WNV, family Flavivirus, was recently described in horses and monkeys in the state of Espírito Santo, Brazil (Silva et al. 2018). The first description of a human case WNV encephalitis in this country was recorded in the state of Piauí, northeast of Brazil, in 2014. Since birds are reservoirs of this virus, monitoring and investigating its presence in wild bird populations is crucial (Vieira et al. 2015a).

Investigation of the Adenoviruses and Herpesviruses that respectively belong to the families Adenoviridae and Herpesviridae were also performed in the present study. AVs are common infectious agents in poultry and wild birds worldwide. In a recent research, samples were collected from birds that belonged to different states in Brazil, the birds analyzed presented with hepatitis-hydropericardium syndrome (HHS), malabsorption syndrome and runtingstunting syndrome, as a result of the investigation many were identified positive to AV (De la Torre et al. 2018). Of the 12 serotypes of fowl AVs reported, most of them are able to cause inclusion body hepatitis and represent a significant risk because may contribute to increased mortality rates (Absalón et al. 2017). Herpesviruses (HVs) cause a broad variety of diseases with distinct clinical presentations and lesions in birds. Recent studies that evaluated different seabird species sampled in coastal areas of the South Atlantic reported occurrences of outbreaks of HV in Magellanic penguins (Spheniscus magellanicus) and in an Atlantic yellow-nosed albatross (Thalassarche chlororhynchos) at a rehabilitation center located in Rio Grande do Sul (Niemeyer et al. 2017). With regard to conservation of threatened species, these diseases can cause adverse impacts on these populations. 
Brazil is the world's largest broiler meat exporter (Nääs et al. 2015) and occurrences of these viral diseases has a huge negative impact on the economy due to trade restrictions and embargoes.

Brazil harbors highly diverse avian communities that remain poorly studied in relation to these viruses. Out of the 1,919 species of birds recorded in Brazil, 198 (10.3\%) are migratory. Some partially migratory species are found in the Pampa biome (Somenzari et al. 2018). Further surveillance efforts to detect these and other avian-borne viruses are necessary, particularly in areas of high avian diversity and endemism (Lugarini et al. 2018).

Considering the absence of information on the circulation of AIV, NDV, WNV, AV and HV among the captive yellow cardinals and wild passerines that are found in the Pampa biome, the aim of the present study was to evaluate the occurrence of these viruses in passerines that inhabit these areas of unique and important vegetation as well as the endangered yellow cardinals of the Captive Program of the Yellow Cardinal.

\section{MATERIALS AND METHODS}

Ethics committee. This study was approved by the Ethics Committee of the "Universidade Federal do Paraná" (UFPR, approval number 038/2018) and by the authorization and biodiversity information system (SISBio) (no. 53935) of the "Instituto Chico Mendes de Conservação da Biodiversidade” (ICMBio).

Study area. Part of the study was developed with wild life passerines and was carried out in the "Parque Estadual do Espinilho" Conservation Unit ( $\left.30^{\circ} 12^{\prime} \mathrm{S} ; 57^{\circ} 30^{\prime} \mathrm{W}\right)$, which is located in the city of Barra do Quaraí, westernmost of Rio Grande do Sul state, Brazil. The Park has the largest area of savanna among the last remnants of this type of vegetation formation in southern Brazil. This vegetation type is associated with the Pampa biome and is composed predominantly by Prosopis affinis (local name: inhanduvá) and Vachellia caven (local name: espinilho) (Marchiori \& Alves 2011). Currently, 15 species of passerines encountered in the southern grassland and thornbush terrains are endangered, including the Gubernatrix cristata. Loss and degradation of these habitats are the main factors that have caused reductions in the populations of the grassland birds, which is also correlated with trafficking, hunting and introduction of exotic species and diseases (Martins-Ferreira et al. 2013).

The other part of the study was held with captive yellow cardinals and carried out with fauna maintainers linked to the Captive Program of the Yellow Cardinal, in the municipalities of Foz do Iguaçu, Pomerode and Gramado, in Brazil. The Yellow Cardinal Captivity Program aims to establish viable captive populations representative in Brazil to contemplate programs of reinvigoration and reintroduction.

Passerines. Passerines of wild life were captured during two field expeditions in the months February and December of 2019. Throughout the February expedition, 62 passerines including one yellow cardinal were captured and in the second expedition two yellow cardinals were captured. In total 64 passerines of wild life were evaluated in this study. To capture the passerines mist nets were used (16 $\mathrm{mm}$ mesh) of $12 \mathrm{~m}$ long and $2.5 \mathrm{~m}$ height at three capture points. Mist nets were reviewed every 20 minutes and the birds captured were placed for a few minutes in individual containment bags for manipulation (biological material collection and banding). The species were identified based on a field guide (Azpiroz 2012). They were immediately released after handling. To capture specimens of the critically endangered yellow cardinal (G. cristata), an active search was performed in the study area using the playback method (i.e. attracting the species using its own song) to attract the individuals. The status of threat of the species follows the Red Book of Brazilian Fauna Threatened with Extinction (ICMBio 2018). The sixty-four (64) individuals of wild life captured belonged to 26 different species of passerines: G. cristata (3), Cranioleuca pyrrhophia (1), Drymornis bridgesii (1), Lepidocolaptes angustirostris (1), Progne tapera (1), Pseudoseisura lophotes (1), Schoeniophylax phryganophilus (1), Saltator aurantiirostris (1), Sublegatus modestus (1), Turdus amaurochalinus (1), Tyrannus melancholicus (1), Coryphistera alaudina (2), Mimus saturninus (2), Molothrus rufoaxillaris (2), Serpophaga subcristata (2), Tangara sayaca (2), Troglodytes musculus (2), Agelaioides badius (3), Asthenes baeri (3), Pyrocephalus rubinus (3), Pitangus sulphuratus (3), Polioptila dumicola (4), Sicalis flaveola (4), Paroaria coronata (5), Furnarius rufus (6) and Zonotrichia capensis (8).

In addition to the wild life passerines, 30 yellow cardinals of captive that were maintained by registered fauna maintainers of the Yellow Cardinal Captivity Program were evaluated in the study. These passerines were; 17 from Parque das Aves, seven from GramadoZoo and six from Zoo Pomerode, all located in south Brazil.

Sample collection. Samples from the cloaca and oropharynx were collected from the evaluated birds using sterile swabs. These samples were placed in cryovials containing phosphate-buffered saline (PBS), glycerol, antibiotic and antifungal media, in accordance with the protocol described in the World Health Organization's manual for diagnosis and surveillance of animal influenza (Webster et al. 2002). The cryovials containing the samples were frozen in liquid nitrogen immediately after sample collection and were kept frozen until the time of the analysis. The analyses were done at the Biosafety Level $3^{+}$Laboratory (BSL3+) of the "Instituto de Ciências Biomédicas", "Universidade de São Paulo" (USP).

RNA and DNA extraction. For RNA and DNA extraction, $300 \mu \mathrm{L}$ of cloacal and oropharyngeal swab samples were used in the MagMAX ${ }^{\text {TM }}$ CORE Nucleic Acid commercial purification kit (Life Technologies Corporation, Austin/TX, USA). The entire extraction process was performed on automated equipment $\left(\right.$ MagMAX $^{\mathrm{TM}}$ Express 96, Applied Biosystems), in accordance with the manufacturer's instructions.

Real-time polymerase chain reaction (RT-PCR). Positive and negative controls were used in each reaction (Table 1). Positive samples previously tested and sequenced in Clinical and Molecular Virology Laboratory were used as positive controls and for negative control we used ultrapure DNAse/RNAse free water.

For detection of AIV, NDV and WNV, the samples were subjected to a one-step RT-PCR reaction using $8.63 \mu \mathrm{L}$ of extracted RNA (for this, the following were added: $12.5 \mu \mathrm{L}$ of $2 \mathrm{x}$ RT-PCR buffer, $1.2 \mu \mathrm{L}$ of 25x AIV-M primer/probe mix, 1.0 $\mu \mathrm{L}$ of 25x RT-PCR enzymes and $1.67 \mu \mathrm{L}$ of detector enhancer (Applied Biosystems, Foster City/CA, USA), totaling $25 \mu \mathrm{L}$ of final reaction volume for AIV (Araujo et al. 2014). For both NDV and WNV, the same methodology as described above for AIV was used with the following alterations: for NDV, the primers and probes already described were used, and the reaction was performed as a multiplex for NDV classes I and II (Kim et al. 2008); for WNV, the specific primers and probes previously described (Ometto et al. 2013) were used.

The conditions were the same for all viruses, i.e. $45^{\circ} \mathrm{C}$ for 20 minutes (reverse transcription), followed by $95^{\circ} \mathrm{C}$ for $10 \mathrm{~min}$ and then 40 cycles of $95^{\circ} \mathrm{C}$ for 15 seconds and $56^{\circ} \mathrm{C}$ for 45 seconds. To make readings and collect data, the 7300 Real Time PCR System ${ }^{\circledR}$ equipment was utilized (Applied Biosystems, Foster City/CA, USA).

Nested PCR. To detect AV and HV, the samples were subjected to nested PCR reactions. DNA amplification was performed using $5 \mu \mathrm{L}$ of DNA, $50 \mathrm{mM}$ of $\mathrm{KCl}$ and, $1.5 \mathrm{mM}$ of $\mathrm{MgCl}_{2}$ as the PCR buffer 
(Invitrogen ${ }^{\circledR}$, Carlsbad/CA, USA), together with 50 pmol of each primer, 2.5U of Taq DNA polymerase (Invitrogen ${ }^{\circledR}$, Carlsbad/CA, USA), $0.2 \mathrm{mM}$ of each dNTP and DEPEC-treated MilliQ water q.s. $100 \mu \mathrm{l}$. The samples were amplified in the GeneAmp PCR System 9700 thermal cycler (Applied Biosystems ${ }^{\circledR}$, Foster City/CA, USA).

Amplification for $\mathrm{HV}$ was performed starting with a $95^{\circ} \mathrm{C}$ step for 5 minutes, followed by 45 cycles of $96^{\circ} \mathrm{C}$ for 5 seconds, $46^{\circ} \mathrm{C}$ for 8 seconds and $68^{\circ} \mathrm{C}$ for 12 seconds, and ending with $72^{\circ} \mathrm{C}$ for 2 minutes. The next step was to perform nested PCR, following the same description mentioned above. A protocol previously described (VanDevanter et al. 1996) was performed using the primers DFA, ILK and KG1 for PCR, and IGV and IYG for nested PCR. In addition, the protocol designated (Chmielewicz et al. 2001) was executed using the primers 707s and 707as for PCR, and 708s and 708as for nested PCR.

DNA amplification for AV was achieved starting with $95^{\circ} \mathrm{C}$ for 10 minutes; followed by 14 cycles of $96^{\circ} \mathrm{C}$ for 30 seconds, $65^{\circ} \mathrm{C}$ for 30 seconds and $72^{\circ} \mathrm{C}$ for 1 minute; then 35 cycles of $95^{\circ} \mathrm{C}$ per 30 seconds, $50^{\circ} \mathrm{C}$ for 30 seconds and $72^{\circ} \mathrm{C}$ for 1 minute; and lastly a final extension of $70^{\circ} \mathrm{C}$ for 7 minutes. The next step was to complete the nested PCR, following the description from above, replacing the primers FLTR and RTR with FNR and RNR, as previously defined (Wellehan et al. 2004).
Agarose gel electrophoresis. Agarose gels at $2 \%$ concentration were produced and added to $2.5 \mu \mathrm{L}$ of ethidium bromide. In the last pool of each gel line, $2 \mu \mathrm{L}$ of molecular weight marker were applied (DNA ladder; $0.25 \mu \mathrm{g} / \mu \mathrm{L}$ ); and in the other pools, $10 \mu \mathrm{L}$ of sample with $3 \mu \mathrm{L}$ of loading buffer $1 \mathrm{X}$ were applied. The gels were electrophoresed at 100 volts for approximately 50 minutes. The samples that presented bands in the nested reaction were considered to be suspected positive samples that would then need to be confirmed by sequencing.

Purification, sequencing and phylogenetic analysis. The positive amplification fragment for AV was purified using Exo-SAP and then the sample was sent to Sanger Sequencing. The sequencing reaction was performed using BigDye kit following manufactures recommendations. To remove the excess dideoxynucleotide terminators with Applied Biosystems Big Dye XTerminatorTM Purification Kit (Applied Biosystems, Foster City/CA) in accordance with the manufacturer's recommendations.

The nucleotide sequences obtained were analyzed using the BLAST program ${ }^{6}$ to confirm amplification of the specific product and the sequences were aligned using Geneious software (version Prime). Phylogenetic analyses were performed using MEGA7 software

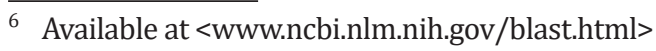

Table 1. Complete information about primers, size of amplicon, targeted genes and references for each assay

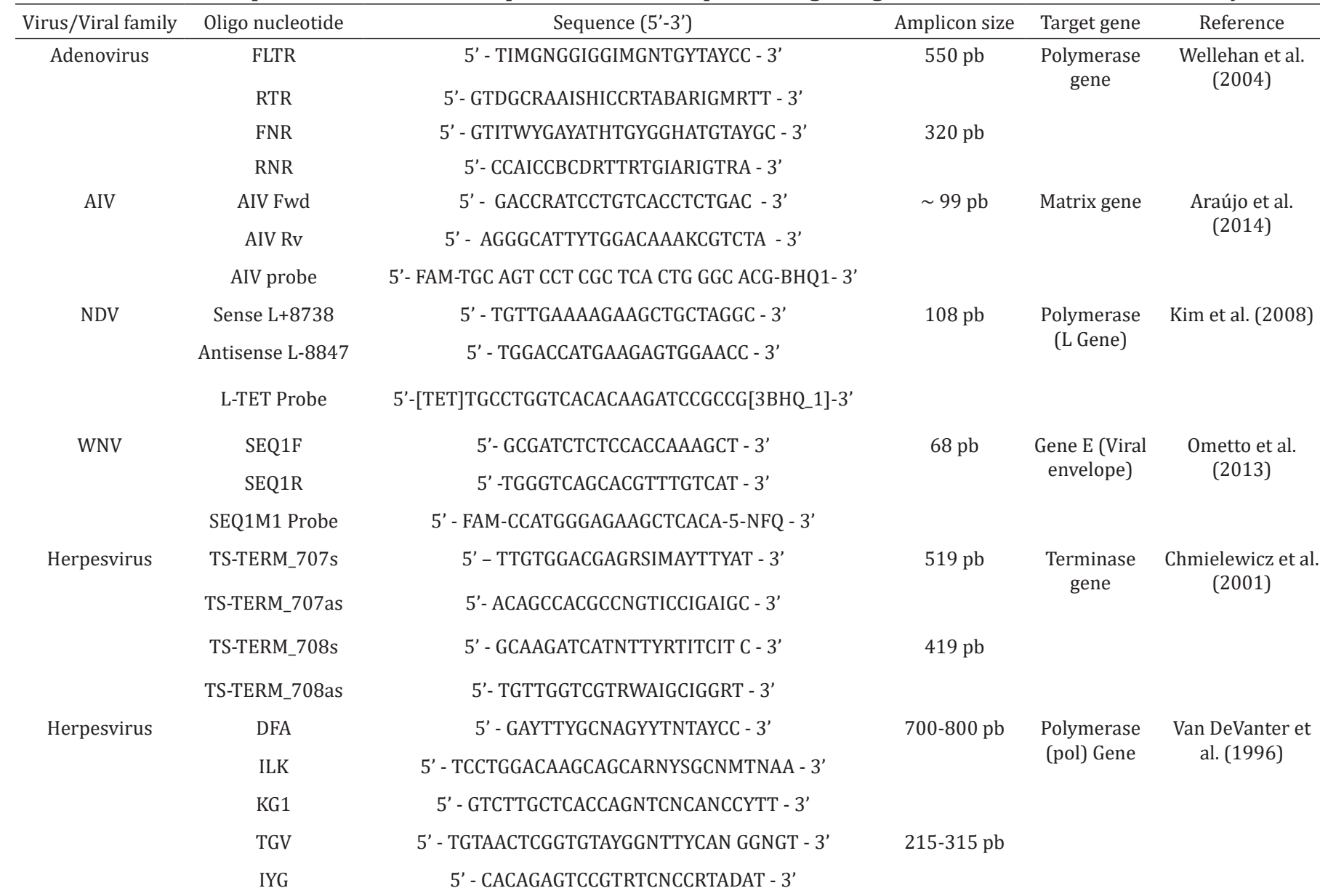


(version 7.0.2) using Maximum Likelihood (ML) with NeighborJoining (NJ) and GTR+Y+I model.

Sequence submission. The sequence was submitted to GenBank under accession number NM602948.

\section{RESULTS}

We studied 94 passerines cloacal and oropharynx samples, of which 64 were of wild life from the "Parque Estadual do Espinilho" and 30 were captive yellow cardinals that belonged to three different fauna maintainers from Brazil. All samples were submitted to AIV, NDV, WNV, AV and HV molecular analysis.

The 64 wild passerines evaluated in the present study were negative for all viruses evaluated according to molecular detection. Among 30 captive yellow cardinals analyzed there was one positive result for $\mathrm{AV}$, this sample was collected on June 7 of 2019. After processing, the sample segregated as Siadenovirus clade (Fig.1), other sequences of this virus were previously isolated from different species such as raptor, south polar skua, great tit, penguin and turkey.
The negative results obtained in the present study are highly relevant because no other similar researches have been performed in this area providing information about the status of relevant viruses between passerines species of wild and captive.

\section{DISCUSSION}

No previous study was found reporting any adenovirus in yellow cardinals and the epidemiological role of this virus remains unknown. Siadenoviruses was previously found in birds (Pitcovski et al. 1998), tortoises (Rivera et al. 2009). In the past it was named as Group II aviadenoviruses, the genus Siadenovirus contains clinically relevant viruses; which includes the hemorrhagic enteritis virus (HEV) of turkey and marble spleen disease virus of pheasants (Fitzgerald \& Reed 1989, Dhama et al. 2017). Siadenovirus was identified in two psittacines that clinically presented weight loss and lethargy, which are non-specific clinical signs, significant clinical differences exist between adenoviral types and species (Wellehan Jr et al. 2009). Raptors infected with siadenovirus

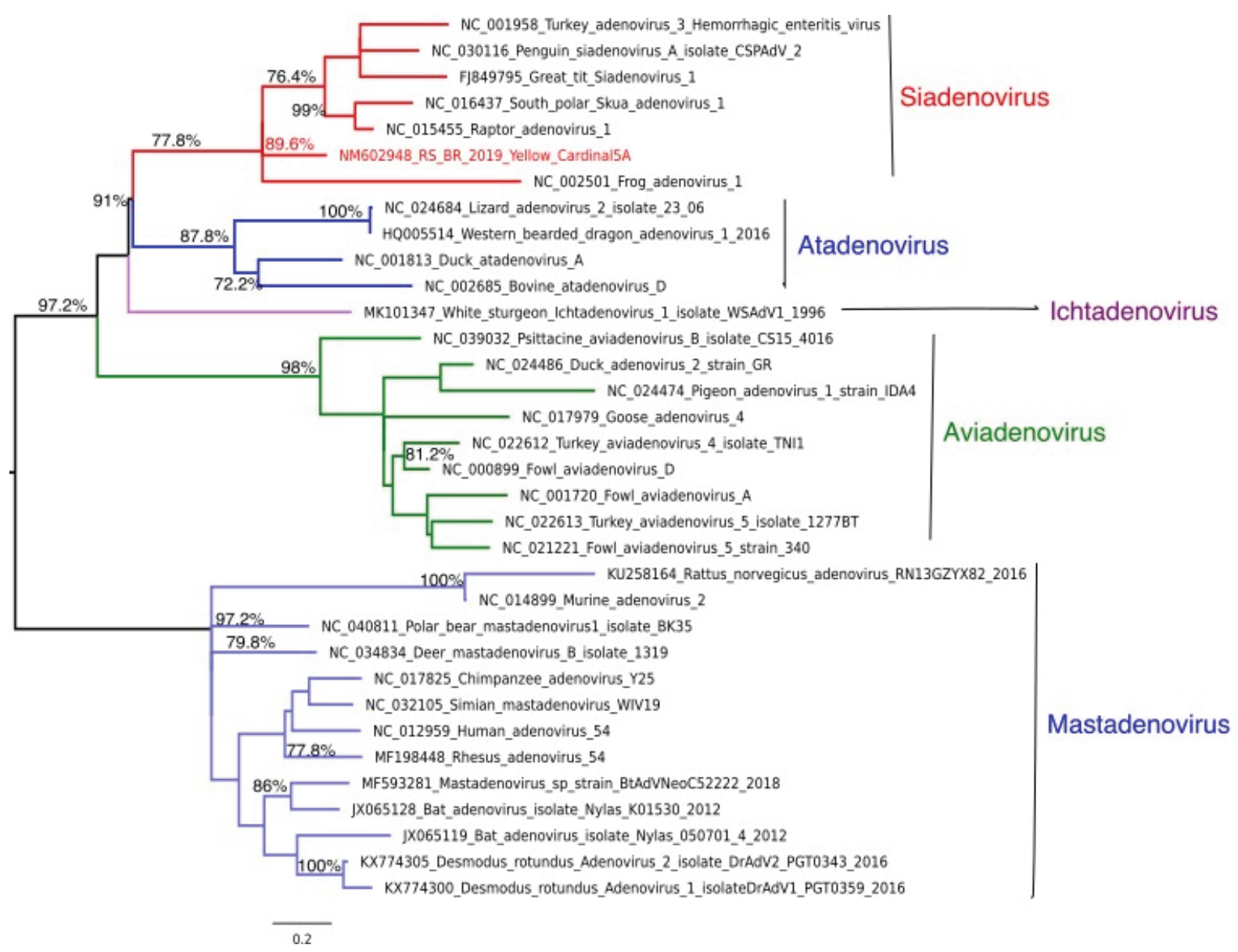

Fig.1. Phylogenetic three of 240 nucleotide polymerase gene. Sequence obtained in this study was highlighted in red. Molecular phylogenetic analysis by maximum likelihood (ML) method. The evolutionary history was inferred by using the ML method based on the General Time Reversible model (GTR). Initial tree(s) for the heuristic search were obtained automatically by applying neighbor-join (NJ) and BioNJ algorithms to a matrix of pairwise distances estimated using the maximum composite likelihood (MCL) approach, and then selecting the topology with superior log likelihood value. A discrete Gamma distribution was used to model evolutionary rate differences among sites ( 5 categories $+\mathrm{G}$ ). The tree is drawn to scale, with branch lengths measured in the number of substitutions per site. Codon positions included were $1 s t+2 n d+3 r d+$ Noncoding. All positions with less than $95 \%$ site coverage were eliminated. The bootstrap value under $75 \%$ was suppressed. Evolutionary analyses were conducted in MEGA7. 
presented severe necrotizing hepatitis with intranuclear inclusion bodies in kidneys and spleen (Zsivanovits et al. 2006). Recent studies conducted an ecoepidemiological analysis on bird and mammal in the Brazilian Cerrado biome using a primer based on the amino acid sequence of the hexon protein, with approximately 900 pairs and they were able to detect AV in a passerine species (Sicalis flaveola) (Duarte et al. 2019). They also used a primer for the conserved polymerase region, as was performed in the present study.

Some species of AV can induce mortality as a primary agent in the absence of other infections or immunosuppression, and it can cause hydropericardium and hepatitis syndrome (HHS) (Mazaheri et al. 1998, Vera-Hernández et al. 2016). HHS is a severe disease that causes mortality up to $100 \%$ in unvaccinated birds (Asthana et al. 2013, Vera-Hernández et al. 2016). If an infectious disease is introduced into a captive population of an endangered species it can be difficult or even impossible to control (Meli et al. 2009). The introduction of uncommon pathogens in a wild population can be very dangerous to their viability (Walker et al. 2008).

Despite having only one positive result for the investigation, this does not rule out the possibility of the circulation of $\mathrm{AV}$ and other viruses in the researched region, because the prevalence of them may vary temporally.

In South America, AIV has already been detected in birds in Brazil, Argentina, Bolivia, Colombia, Chile and Peru. In 2002, there was an outbreak of highly pathogenic AIV in commercial poultry in Chile (Hurtado \& Vanstreels 2016). In Brazil, AIV of low pathogenic level was detected via PCR in migratory birds in the Amazon region, and serologically positive animals were detected in the state of São Paulo (Araujo et al. 2014, Sousa et al. 2013). Although Brazil is considered to be free from highly pathogenic AIV, further studies are urgently needed in order to evaluate the susceptibility of infections across different orders and families of South American birds.

NDV has been reported in Brazil, in captive ducks in the northern region and in free-living Charadriiformes on the northeastern coast, this study tested 1022 domestic and wild birds reporting the presence of NDV in $0,7 \%$ of the birds (Thomazelli et al. 2012). However, no positive results were found in the present study.

No presence of WNV has yet been detected in birds in Brazil. Among serum samples from five common terns (Sterna hirundo) in Rio Grande do Sul, three of them were found to be positive according to the ELISA technique. However, the plaque reduction neutralization test did not confirm these findings (Ometto et al. 2013). Nonetheless, WNV has been detected in humans in Brazil (Vieira et al. 2015b). Given that this virus is maintained in nature in passerines, and that they can develop sufficient viremia to infect the mosquitoes that feed on them, these birds are competent amplifying hosts and need to be monitored.

This is the first report of $A V$ in yellow cardinal and investigation of AIV, NDV, WNV, AV and HV in two critically endangered passerine species: the yellow cardinal (Gubernatrix cristata) and lark-like brushrunner (Coryphistera alaudina). However, monitoring pathogens in wild birds has limitations and caution is warranted when making a larger scale projection about current or future distribution based on a small sample size in a specific location (Van Hemert et al. 2019).

\section{CONCLUSION}

In the present study one yellow cardinal of captive was positive to adenovirus (AV) meanwhile, avian influenza viruses (AIVs), Newcastle disease virus (NDV), West Nile virus (WNV), and herpesvirus (HV) were not detected in the other 93 passerines evaluated. This is an important result because it provides information on the health situation of these wild and captive grassland passerines of south Brazil for the first time and is primordial for the conservation of species, more specifically the critically endangered yellow cardinal.

Acknowledgements.- We wish to thank "Secretaria do Meio Ambiente do Rio Grande do Sul" (SEMA-RS) and "Parque Estadual do Espinilho" staff for permitting to research on a protected area, and "Fazenda São Marcos" owners for granting access to a study site. We also thank "Condomínio Agropecuário Ceolin" for its huge support. C. S. Fontana for their fieldwork assistance and for suggestions and comments. This study was funded by the "Conselho Nacional de Desenvolvimento Científico e Tecnológico" (CNPq 422053/2016-3). Thanks to another author's Scholarship: ACAC (post-doc Process FAPESP 2014/15090-8).

Conflict of interest statement.- The authors declare no conflict of interest. The founding sponsors had no role in the design of the study; in the collection, analyses, or interpretation of data; in the writing of the manuscript, and in the decision to publish the results.

\section{REFERENCES}

Absalón A.E., Morales-Garzón A., Vera-Hernández P.F., Cortés-Espinosa D.V., Uribe-Ochoa S.M., García L.J. \& Lucio-Decanini E. 2017. Complete genome sequence of a non-pathogenic strain of Fowl Adenovirus serotype 11: minimal genomic differences between pathogenic and nonpathogenic viruses. Virology 501:63-69. <https://dx.doi.org/10.1016/j.virol.2016.11.006> <PMid:27865971>

Araujo J., Azevedo Júnior S.M., Gaidet N., Hurtado R., Walker D., Thomazelli L.M., Ometto T., Seixas M.M.M., Rodrigues R., Galindo D.B., Silva A.C.S., Rodrigues A.M.M., Bomfim L.L., Mota M.A., Larrazábal M.E., Branco J.O., Serafini P., Neto I.S., Franks J., Webby R.J., Webster R.G. \& Durigon E.L. 2014. Avian influenza virus (H11N9) in migratory shorebirds wintering in the Amazon Region, Brazil. PLoS One 9(10):e110141. <https://dx.doi. org/10.1371/journal.pone.0110141><PMid:25329399>

Araujo J., Petry M.V., Fabrizio T., Walker D., Ometto T., Thomazelli L.M., Scherer A.L., Serafini P.P., Neto I.S., Krauss S., Webster R.G., Webby R.J. \& Durigon E.L. 2018. Migratory birds in southern Brazil are a source of multiple avian influenza virus subtypes. Influenza Other Respir. Viruses 12(2):220231. <https://dx.doi.org/10.1111/irv.12519> <PMid:29143465>

Asthana M., Chandra R. \& Kumar R. 2013. Hydropericardium syndrome: current state and future developments. Arch. Virol. 158(5):921-931. <https://dx.doi.org/10.1007/s00705-012-1570-x> <PMid:23242777>

Azpiroz A.B. 2012. Aves de las Pampas y Campos de Argentina, Brasil y Uruguay: una guia de identificación. Pressur, Nueva Helvecia, Uruguay.

Beier C., Repenning M., Pereira M., Pereira A. \& Fontana C. 2017. Cooperative breeding and demography of Yellow Cardinal Gubernatrix cristata in Brazil. Revta Bras. Ornitol., Braz. J. Ornithol. 25(1):12-19. <https://dx.doi. org/10.1007/BF03544371>

Bello M.B., Yusoff K., Ideris A., Hair-Bejo M., Peeters B. \& Omar A.R. 2018. Diagnostic and vaccination approaches for Newcastle disease virus in poultry: the current and emerging perspectives. BioMed Res. Int. 2018(4):118. <https://dx.doi.org/10.1155/2018/7278459> <PMid:30175140>

Caron A., Cappelle J. \& Gaidet N. 2017. Challenging the conceptual framework of maintenance hosts for influenza A viruses in wild birds. J. Appl. Ecol. 54(3):681-690. <https://dx.doi.org/10.1111/1365-2664.12839> 
Chmielewicz B., Goltz M. \& Ehlers B. 2001. Detection and multigenic characterization of a novel gammaherpesvirus in goats. Virus Res. 75(1):87-94. <https:// dx.doi.org/10.1016/s0168-1702(00)00252-5><PMid:11311431>

De la Torre D., Nuñez L., Santander Parra S.H., Astolfi-Ferreira C.S. \& Piantino Ferreira A.J. 2018. Molecular characterization of fowl adenovirus group I in commercial broiler chickens in Brazil. Virusdisease 29(1):83-88. <https://dx.doi.org/10.1007/s13337-018-0430-z> <PMid:29607363>

Dhama K., Gowthaman V., Karthik K., Tiwari R., Sachan S., Kumar M.A., Palanivelu M., Malik Y.S., Singh R.K. \& Munir M. 2017. Haemorrhagic enteritis of turkeys - current knowledge. Vet. Q. 37(1):31-42. <https://dx.doi.org/ 10.1080/01652176.2016.1277281> <PMid:28024457>

Dimitrov K.M., Ramey A.M., Qiu X., Bahl J. \& Afonso C.L. 2016. Temporal, geographic, and host distribution of avian paramyxovirus 1 (Newcastle disease virus). Infect. Genet. Evol. 39:22-34.<https://dx.doi.org/10.1016/j. meegid.2016.01.008><PMid:26792710>

Duarte M.A., Silva J.M.F., Brito C.R., Teixeira D.S., Melo F.L., Ribeiro B.M., Nagata T. \& Campos F.S. 2019. Faecal virome analysis of wild animals from Brazil. Viruses 11(9):803-826. <https://dx.doi.org/10.3390/v11090803> $<$ PMid:31480274>

Fitzgerald S.D. \& Reed W.M. 1989. A review of marble spleen disease of ring-necked pheasants. J. Wildl. Dis. 25(4):455-461. <https://dx.doi. org/10.7589/0090-3558-25.4.455><PMid:2553999>

Hurtado R. \& Vanstreels R.E.T. 2016. Avian influenza in wild birds from South America: review, implications and perspectives. Explor. Res. Hypothesis Med. 1(4):62-74. <https://dx.doi.org/10.14218/ERHM.2016.00014>

ICMBio 2018. Livro Vermelho da Fauna Brasileira Ameaçada de Extinção. Vol.1. Instituto Chico Mendes de Conservação da Biodiversidade, Brasília, DF.

Jaramillo A. 2020. Yellow Cardinal (Gubernatrix cristata), version 1.0. In: del Hoyo J., Elliott A., Sargatal J., Christie D.A. \& de Juana E. (Eds), Birds of the World. Cornell Lab of Ornithology, Ithaca, NY. <https://dx.doi. org/10.2173/bow.yelcar1.01>

Kalthoff D., Globig A. \& Beer M. 2010. (Highly pathogenic) avian influenza as a zoonotic agent. Vet. Microbiol. 140(3/4):237-245. <https://dx.doi. org/10.1016/j.vetmic.2009.08.022><PMid:19782482>

Kim L.M., Suarez D.L. \& Afonso C.L. 2008. Detection of a broad range of class I and II Newcastle disease viruses using a multiplex real-time reverse transcription polymerase chain reaction assay. J. Vet. Diagn. Invest. 20(4):414-425. <https://dx.doi.org/10.1177/104063870802000402> $<$ PMid:18599845>

Kolesnikovas C.K., Niemeyer C., Teixeira R.H., Nunes A.L., Rameh-de-Albuquerque L.C., Sant'Anna S.S. \& Catão-Dias J.L. 2012. Hematologic and plasma biochemical values of Hyacinth Macaw (Anodorhynchus hyacinthinus). J. Avian Med.Surg. 26(3):125-129. <https://dx.doi.org/10.1647/2011-020r1.1> <PMid:23156973>

Lugarini C., Hurtado R., Araujo J., Ometto T., Thomazelli L.M., Seixas M.M.M., Durigon E. \& Silva J.C. 2018. Lack of Detection of Avian Influenza, Newcastle Disease, and West Nile Viruses in Wild Birds of Northeastern Brazil. J. Wildl. Dis. 54(2):422-425. <https://dx.doi.org/10.7589/2017-09-218> $<$ PMid:29148889>

Marchiori J.N.C. \& Alves F.S. 2011. 0 inhanduvá (Prosopis affinis Spreng.) no Rio Grande do Sul. 8 - Aspectos fitogeográficos. Balduinia (29):13-20. <https://dx.doi.org/10.5902/2358198014133>

Marks F.S., Rodenbusch C.R., Okino C.H., Hein H.E., Costa E.F., Machado G., Canal C.W., Bretano L. \& Corbellini L.G. 2014. Targeted survey of Newcastle disease virus in backyard poultry flocks located in wintering site for migratory birds from Southern Brazil. Prev. Vet. Med. 116(1/2):197-202. <https://dx.doi.org/10.1016/j.prevetmed.2014.06.001><PMid:24958456>

Martins-Ferreira C., Bencke G.A., Fontana C.S., Dias R.A., Repenning M., Damiani R.V., Mauricio G.N., Gianuca A.T., Krügel M.M., Franz I., Rovedder C.E., Rupp A.E., Pereira M.S., Vizentin-Bugoni J., Joenck C.M., Straube F.C., Reinert B.L., Bornschein M.R., Dias D., Vieira B.P. \& Serafini P.P. 2013. Plano de Ação Nacional para a conservação dos Passeriformes ameaçados dos Campos Sulinos e Espinilho. Série Espécies Ameaçadas 31, Instituto Chico Mendes de Conservação da Biodiversidade (ICMBio), Brasília, DF.

Mazaheri A., Prusas C., Voß M. \& Hess M. 1998. Some strains of serotype 4 fowl adenoviruses cause inclusion body hepatitis and hydropericardium syndrome in chickens. Avian Pathol. 27(3):269-276. <https://dx.doi. org/10.1080/03079459808419335><PMid:18483997>

Meli M.L., Cattori V., Martínez F., López G., Vargas A., Simón M.A., Zorrilla I., Muñoz A., Palomares F., López-Bao J. V., Pastor J., Tandon R., Willi B., Hofmann-Lehmann R. \& Lutz H. 2009. Feline leukemia virus and other pathogens as important threats to the survival of the critically endangered Iberian lynx (Lynx pardinus). PLoS One. 4(3)e4744. <https://dx.doi. org/10.1371/journal.pone.0004744><PMid:19270739>

Nääs I.A., Mollo Neto M., Canuto S., Waker R., Oliveira D. \& Vendametto 0. 2015. Brazilian chicken meat production chain: a 10-year overview. Braz. J. Poult. Sci. 17(1):87-94. <https://dx.doi.org/10.1590/1516-635x170187-94>

Niemeyer C., Favero C.M., Shivaprasad H.L., Uhart M., Musso C.M., Rago M.V., Silva-Filho R.P., Canabarro P.L., Craig M.I., Olivera V., Pereda A., Brandão P.E. \& Catão-Dias J.L. 2017. Genetically diverse herpesviruses in South American Atlantic coast seabirds. PLoS One. 12(6):e0178811. <https://dx.doi.org/10.1371/journal.pone.0178811><PMid:28575104>

Ometto T., Durigon E.L., Araujo J., Aprelon R., Aguiar D.M., Cavalcante G.T., Melo R.M., Levi J.E., Azevedo Júnior S.M., Petry M.V., Simão Neto I., Serafini P., Villalobos E., Cunha E.M.S., Lara M.C.C.S.H., Nava A.F.D., Nardi M.S., Hurtado R., Rodrigues R., Sherer A.L., Shererh J.F.M., Geraldi M.P., Seixas M.M.M., Peterka C., Bandeira D.S., Pradel J., Vachiery N., Labruna M.B., Camargo L.M.A., Lanciotti R. \& Lefrançois T. 2013. West nile virus surveillance, Brazil, 2008-2010. Trans. R. Soc. Trop. Med. Hyg. 107(11):723-730. <https://dx.doi.org/10.1093/trstmh/trt081> <PMid:24008895>

Pitcovski J., Goldberg D., Levi B.Z., Di-Castro D., Azriel A., Krispel S., Maray T. \& Shaaltiel Y. 1998. Coding region of segment A sequence of a very virulent isolate of IBDV - comparison with isolates from different countries and virulence. Avian Dis. 42(3):497-506. <PMid:9777150>

Rivera S., Wellehan Jr. J.F.X., McManamon R., Innis C.J., Garner M.M., Raphael B.L., Gregory C.R., Latimer K.S., Rodriguez C.E., Diaz-Figueroa O., Marlar A.B., Nyaoke A., Gates A.E., Gilbert K., Childress A.L., Risatti G.R. \& Frasca Jr. S. 2009. Systemic adenovirus infection in Sulawesi tortoises (Indotestudo forsteni) caused by a novel siadenovirus. J. Vet. Diagn. Invest. 21(4):415-426. <https://dx.doi.org/10.1177/104063870902100402><PMid:19564489>

Silva A.S.G., Matos A.C.D., Cunha M.A.C.R., Rehfeld I., Galinari G.C.F., Marcelino S.A.C., Saraiva L.H.G., Martins N.R.S., Maranhão R.P.A., Lobato Z.I.P., Pierezan F., Guedes M.I.M.C. \& Costa E.A. 2019. West Nile virus associated with equid encephalitis in Brazil, 2018. Transb. Emerg. Dis. 66(1):445-453. <https://dx.doi.org/10.1111/tbed.13043><PMid:30318735>

Somenzari M., Amaral P.P., Cueto V.R., Guaraldo A.C., Jahn A.E., Lima D.M., Lugarini C., Machado C.G., Martinez J., Nascimento J.L.X., Pacheco J.F., Paludo D., Prestes N.P., Serafini P.P., Silveira L.F., Sousa A.E.B.A., Sousa N.A., Souza M.A., Telino-Júnio W.R. \& Whitney B.M. 2018. An overview of migratory birds in Brazil. Papéis Avulsos Zool. 58:e20185803. <https://dx.doi.org/10.11606/1807-0205/2018.58.03>

Sousa E., Costa T.P., Werther K., Dugon E.L., De Araujo J., Ferreira C. \& Pinto A. 2013. Presence of antibodies against $\mathrm{H} 5, \mathrm{H} 7$ and $\mathrm{H} 9$ influenza $\mathrm{A}$ virus in wild birds in the state of São Paulo, Brazil. Braz. J. Poult. Sci. 15(3):169-286. <https://dx.doi.org/10.1590/S1516-635X2013000300001>

Thomazelli L.M., De Araujo J., Ferreira C.S., Hurtado R., Oliveira D.B.L., Ometto T., Golono M., Sanfilippo L., Demetrio C., Figueiredo M.L. \& Durigon E.L. 2012. Molecular surveillance of the Newcastle disease virus in domestic and wild birds on the north eastern coast and amazon bioma of Brazil. Braz. J. Poult. Sci. 14(1):1-7.<https://dx.doi.org/10.1590/S1516-635X2012000100001>

Tian H. \& Xu B. 2015. Anthropogenic factors and societal response to challenges in the transmission of highly pathogenic avian influenza A (H5N1). Annals of GIS 21(2):149-156. <https://dx.doi.org/10.1080/19 475683.2015.1027790> 
Urig H.E., Nolting J.M., Mathys D.A., Mathys B.A. \& Bolman A. 2017. Influenza A Virus Surveillance in Underrepresented Avian Species in Ohio, USA, in 2015. J. Wildl. Dis. 53(2):402-404. <https://dx.doi.org/10.7589/2016-05-106> <PMid:28051568>

Van Hemert C., Meixell B.W., Smith M.M. \& Handel C.M. 2019. Prevalence and diversity of avian blood parasites in a resident northern passerine. Parasites Vectors 12:292. <https://dx.doi.org/10.1186/s13071-019-3545-1>

VanDevanter D.R., Warrener P., Bennett L., Schultz E.R., Couter S., Garber R.L. \& Rose T.M. 1996. Detection and analysis of diverse herpesviral species by consensus primer PCR. J. Clin. Microbiol. 34(7):1666-1671. <https://dx.doi.org/10.1128/JCM.34.7.1666-1671.1996><PMid:8784566>

Vera-Hernández P.F., Morales-Garzón A., Cortés-Espinosa D.V., GalioteFlores A., García-Barrera L.J., Rodríguez-Galindo E.T., Toscano-Contreras A., Lucio-Decanini E.L. \& Absalón A.E. 2016. Clinicopathological characterization and genomic sequence differences observed in a highly virulent fowl Aviadenovirus serotype 4. Avian Pathol. 45(1):73-81. <https://dx.doi.org/10.1080/03079457.2015.1125443><PMid:26610321>

Vieira M.A., Romano A.P.M., Borba A.S., Silva E.V.P., Chiang J.O., Eulálio K.D., Azevedo R.S.S., Rodrigues S.G., Almeida-Neto W.S. \& Vasconcelos P.F.C. 2015a. West Nile virus encephalitis: the first human case recorded in Brazil. Am. J. Trop. Med. Hyg. 93(2):377-379. <https://dx.doi.org/10.4269/ ajtmh.15-0170> <PMid:26055749>

Vieira M.A.C.S., Aguiar A.A.X., Borba A.S., Guimarães H.C.L., Eulálio K.D. Albuquerque Neto L.L. \& Lima O.B. 2015b. West Nile fever in Brazil: sporadic case, silent endemic disease or epidemic in its initial stages?
Revta Inst. Med. Trop. S. Paulo 57(3):276. <https://dx.doi.org/10.1590/ S0036-46652015000300017>

Walker S.F., Bosch J., James T.Y., Litvintseva A.P., Oliver Valls J.A., Piña S., García G., Rosa G.A., Cunningham A.A., Hole S., Griffiths R. \& Fisher M.C. 2008. Invasive pathogens threaten species recovery programs. Curr. Biol. 18(18):R853-R854. <https://dx.doi.org/10.1016/j.cub.2008.07.033>

Webster R., Cox N. \& Stöhr K. 2002. Manual on animal influenza diagnosis and Surveillance Global Influenza Programme. World Health Organization, Geneva. 99p

Wellehan J.F., Johnson A.J., Harrach B., Benkö M., Pessier A., Johnson C.M., Garner M.M., Childress A. \& Jacobson E.R. 2004. Detection and analysis of six lizard adenoviruses by consensus primer PCR provides further evidence of a reptilian origin for the atadenoviruses. J. Virol. 78(23):1336613369. <https://dx.doi.org/10.1128/JVI.78.23.13366-13369.2004> $<$ PMid:15542689>

Wellehan Jr J.F., Greenacre C.B., Fleming G.J., Stetter M.D., Childress A.L. \& Terrell S.P. 2009. Siadenovirus infection in two psittacine bird species. Avian Pathol. 38(5):413-417. <https://dx.doi.org/10.1080/03079450903183660> <PMid:19937528>

Zsivanovits P., Monks D.M., Forbes N.A., Ursu K., Raue R. \& Benkö M. 2006. Presumptive identification of a novel adenovirus in a Harris hawk (Parabuteo unicinctus), a Bengal eagle owl (Bubo bengalensis), and a Verreaux's eagle owl (Bubo lacteus). J. Avian Med. Surg. 20(2):105-112. <https://dx.doi. org/10.1647/2005-008.1> 